\author{
Adam RADOMYSKI \\ Military University of Aviation, Faculty of Aviation Safety, Dęblin, Poland \\ Daniel MICHALSKI \\ Military University of Aviation, Faculty of Aviation Safety, Dęblin, Poland
}

\title{
A Diagnosis of Russia's Military Capability in a Situation of an Escalation of Hostility in Ukraine and Possible Implications for the Safety of the Eastern NATO Flank ${ }^{*}$
}

\section{Diagnoza zdolności militarnych Rosji w sytuacji eskalacji wrogich działań na Ukrainie oraz możliwe implikacje dla bezpieczeństwa wschodniej flanki NATO}

\section{- Abstract •}

The paper presents the results of research, whose main goal is to evaluate the aviation and rocket capability of the armed forces of the Russian Federation and Ukraine in terms of a possible launch of regular warfare. The authors primarily focus on changes in the military doctrine of the Russian Federation, which have created legal determinants of the use of armed forces outside the country's territory in defense of national minorities, illustrated by taking control of Crimea. The authors also stress Russia's military plans,

\section{- Abstrakt •}

W artykule przedstawiono wyniki badań, których głównym celem była ocena zdolności lotniczej i rakietowej sił zbrojnych Federacji Rosyjskiej i Ukrainy pod kątem możliwości rozpoczęcia regularnych działań wojennych. Autorzy skupiają się przede wszystkim na zmianach doktryny wojskowej Federacji Rosyjskiej, która stworzyła prawne uwarunkowania użycia sił poza terytorium kraju w obronie mniejszości narodowych, czego przykładem stało się przejęcie kontroli nad Krymem. Autorzy podkre-

* The article is an outcome of the research project "Automation of air defence's information and decision making processes in the modelled environment of air threat to armed forces and critical infrastructure objects", No. GB/5/2018/209/2018/DA, funded by the Ministry of National Defence in the years 2018-2022. 
including the development directions of the potential of armed forces as well as a possible threat to the security of the eastern NATO's flank in the event of a conflict in Ukraine. In this respect, the capabilities of the air defense of countries on the eastern NATO flank, particularly Poland's capability, were analyzed.

Keywords: air defense system; ballistic missiles; air potential; military doctrine; missile anti-aircraft systems; anti-aircraft artillery; air offensive operation; defensive air operation ślają również plany wojskowe Rosji w kierunku rozwoju potencjału sił zbrojnych, a także ewentualne zagrożenie bezpieczeństwa wschodniej flanki NATO w przypadku konfliktu na Ukrainie. W tym zakresie przeanalizowano zdolności obrony powietrznej państw wschodniej flanki NATO, w szczególności Polski.

Słowa kluczowe: system obrony powietrznej; pociski balistyczne; potencjał lotniczy; doktryna wojskowa; przeciwlotnicze systemy rakietowe; artyleria przeciwlotnicza; lotnictwo ofensywne; defensywna operacja powietrzna

\section{Introduction}

The armed conflict in eastern Ukraine has lasted since 2014. A peaceful solution to the "Ukrainian crisis" seems achievable, however it requires a mutual agreement. Since the beginning of the conflict, there have been several ceasefire attempts, yet they proved inefficient due to the fact that today both sides of the conflict are unable to find a common platform for peace talks. In this situation, the conflict may escalate with serious consequences for NATO countries, and we all have been witnesses of this dangerous situation recently in March 2021.

A vast majority of military experts who have analyzed the military potentials of Ukraine and Russia are convinced that in an open conflict with the Russian military, the Ukrainian armed forces would have hardly any chances of achieving success. This is due to a large disproportion in the potential of these countries, both in the quantitative and qualitative sphere (Giles, 2015).

At this point, it is worth stressing that since the war in Georgia in 2008, the armed forces of Russia have been undergoing thorough modernization intended to improve their operational capability and efficiency, not only within the defensive operations on its own territory, but also in the expeditionary activities, which by their nature are undertaken beyond the country's borders. The necessity to make a thoroughgoing reconstruction of the armed forces also arises from the provisions contained in new doctrinal documents. Such actions entail not only changes in the security environment of Ukraine, but also that of NATO, and in particular its eastern flank.

No doubt the world will not be the same after Ukrainian crisis (Larrabee et al., 2017), but what if the conflict escalates? In view of the ongoing conflict in Ukraine and the process of modernization of the Russian Federation, the authors diagnosed 
the military capabilities of the Russian Federation, in the case of a conflict escalation and its impact on the security of NATO's eastern flank. Particular attention was drawn to air security. When analyzing the course of contemporary armed conflicts, there is no doubt that the air force is the backbone of the combat capabilities of the modern armed forces.

The main research problem was formulated as the following question: "How would the capabilities of the armed forces of the Russian Federation change in the case of a conflict escalation in eastern Ukraine, and how would it affect the security of the eastern NATO flank?" In order to answer this question, the authors analyzed available literature, specifying the following issues: the relevance of changes in Russia's military strategy on the security of Ukraine; the impact of the Russian concept of Crimea's militarization on the level of security in Ukraine; the participation of the Russian air force and air-defense forces in the event of conflict escalation and ways of countering air threats by Ukrainian air defense. Finally, the authors attempted to specify a possible threat to air defense of NATO's eastern flank.

\section{The Significance of Changes in Russia's Military Strategy on Ukraine's Security}

With regard to the use of the Russian military forces in Crimea and in the eastern part of Ukraine, there is no doubt that they result from strategic plans which have been prepared over the last few years. The basis for their development were operations undertaken by the Russian Federation after the war with Georgia in 2008. They were aimed at reforming the armed forces. Based on the experience of the war with Georgia, detailed analyses were made, which served as a foundation for a new national security strategy (The Strategy..., 2009) and military strategy. At this point, it is worth noting that one of the key foundations of the new security strategy was the catalogue of threats to the Russian Federation. It was also specified in previous documents, i.e., in the security strategy of 2000, which constituted a reflection of the threats resulting from NATO Allied Force Operation in Kosovo in 1999. This time, however, an identified range of threats was dominated by the warfare in Georgia.

Invariably for decades, the North Atlantic Treaty Organization has topped the list of existing threats. This is essentially due to the fact that Russia believes that the currently existing security architecture in Europe is not adapted to the requirements posed by contemporary threats. Thus, the new Russian strategy clearly reflects the concept of a new security architecture in the Old Continent, proposed in 
June 2008 by Dmitry Medvedev, in which the USA and NATO are perceived as the main external threats (Jankowski, 2009, p. 3). In addition, it was underlined in the new strategy that for Russia, the main threat comes from a unilateral use of force in international relations. However, the list of threats listed in the strategy is much longer. They embrace, among others: the proliferation of weapons of mass destruction, which is directly linked to the threat of its possession by fanatical political groups, cyber terrorism, xenophobia, separatism, demographic problems, operations of organized criminal groups, or pandemics (Jankowski, 2009, p. 4). Special attention needs to be drawn, however, to resource wars, also staged near the borders of the Russian Federation, as a potential external threat to the state ${ }^{1}$.

The state security strategy clearly affected the military doctrine of the Russian Federation adopted on February 5, 2010, which allows the use of the Russian Armed Forces in order to "repel aggression against it and (or) its allies, maintain (restore) peace, acting on the decision taken by the UN Security Council, other organizations of collective security and to defend its own citizens, outside the borders of the Russian Federation [...]" (Cichocki, 2010, p. 36). In accordance with the adopted military doctrine, the Russian Federation's air force will constitute a homogeneous organizational structure with a balanced combat composition. Achieving these objectives will ensure that the equipment of the Russian Air Force in modern aircrafts will possess precision conventional weapons and the possibility of using nuclear weapons. Following the adopted military assumptions, the air force is the most important aggressive and defensive type of armed forces of Russia, forming a solid basis for the airspace defense of the country (Sinicyn, 1998, p. 8). The new organizational structure of the air force includes strategic, bomb, ground attack, fighter, reconnaissance, transport, special purpose aviation. A similar role must be fulfilled by the air force in the armed forces of Belarus and Ukraine, although their task scope is narrower, mainly due to a lower air potential than in the case of Russia.

According to the assurances made by President Vladimir Putin in 2014, the units are to be rearmed, among others, with 210 combat aircraft and helicopters, more than 250 armored vehicles and 40 ICBMs, and the ratio of modern armament is to reach $30 \%$. By the year 2020 , for procurements, as well as research and

1 The term "resource wars" in security strategy refers to energy issues which, since the Vladimir Putin's first term-in-office, have incessantly exerted a crucial role in Russia's foreign policy. It is possible to observe the fading influence of the Russian Federation which is rich in natural resources, primarily oil and gas. 
development, Moscow plans to spend an equivalent of approximately 700 billion dollars. Ultimately, this ratio is set to rise by $70 \%$.

In the Russian strategic triad, ground-based ballistic missiles have played and continue to play a leading role, hence the emphasis on the development of mobile systems, which are far less vulnerable to the threat of damage, and a return to multiple-warhead missiles, guaranteeing the ability to destroy a maximum number of targets with a minimal number of missiles.

\section{The Russian Concept of the Militarization of Crimea and Its Impact on Ukraine's Level of Security}

Russia's annexation of Crimea has significantly changed the existing balance of power in the Black Sea region ${ }^{2}$. In the regional dimension, the ability of the Russian Federation's Armed Forces impact on the other regions of eastern Ukraine has largely increased. It also facilitates the implementation of a gradual acquisition of new territories within its sphere of interests ${ }^{3}$. In Crimea, stronger ties with Russia rather than with Ukraine had existed much earlier. Judging by the survey of June 2013 conducted by Razumkov Center in Kiev, merely 31\% of the population in Crimea supported the independence of Ukraine, and 36\% of inhabitants were opposed. The latter group is mainly composed of Russians. On the other hand, the minority which consists of Ukrainians and Tatars, feels strong links to Ukraine and opposed the postulates voiced by the separatists in Crimea.

The first "victim" of the operations in Crimea was the Black Sea Fleet stationed in Sevastopol ${ }^{4}$, which should have been withdrawn from the territory of Ukraine

2 Respect for the territorial integrity of Ukraine (including Crimea in Ukraine's borders) was guaranteed by the agreement named the Budapest Memorandum, signed in Budapest by Russia, USA, Great Britain, and Ukraine in December 1994.

3 According to the most recent census in Ukraine conducted in 2001, Crimea's population is comprised of 58.5\% Russians, 24.4\% Ukrainians, $12.1 \%$ Crimean Tatars, and $1.5 \%$ Belarusians. In Sevastopol, Russians constitute $71.6 \%$ of the population, Ukrainians - 22,4\%, whereas Belarusians $-1.6 \%$. The language which is dominant in the peninsula is Russian.

4 The Black Sea Fleet was created by Prince Grigory Potemkin on May 13, 1783. Throughout all of its history, it was stationed in Sevastopol. The main shipyard, which is engaged in the construction and maintenance of ships, is located in Mykolaiv (also known as Nikolayev), a city situated on the territory of Crimea. However, Moscow is expanding its shipyard and the port in Novorossiysk in case of any problems with the base in Crimea. Almost all of the Russian vessels stationed in Sevastopol are obsolete. Due to the lack of funds for overhauls, many of them are also in a very poor technical condition. 
in 2017; however, the agreement was extended by 25 years with an option for another 5 years 5 .

Experts indicate that the Crimean Peninsula, cut off from Ukraine, may become a dry wasteland, devoid of electricity and gas, which Russia will have to redevelop at great cost. The peninsula is linked to the mainland of Ukraine with the Isthmus of Perekop, a mere of seven kilometers, a bloodline for all that moves, sustaining Crimean economy and approximately 2 million inhabitants ${ }^{6}$. Despite numerous concerns raised by experts, one should bear in mind the Russian government's far-reaching plans with regard to Crimea's future. In this regard, by 2020, Russia intends to complete its investments on the territory of the annexed Crimean peninsula. Such provisions were adopted by the Russian Ministry of Defense. As a result of these investments, different spheres will become reinforced, including the creation of new units of ground troops, infrastructure development, social and medical security, modern equipment and weapons for the military. The task is spread in time since, in the opinion of the Russian military, Crimea is not endangered by military insecurity nor is there a need to strengthen antagonisms with the West (Cielma, 2014). In accordance with the conceptual assumptions, the main base for the Black Sea Submarine Fleet ${ }^{7}$ is to be created in Sevastopol. Moreover, the units of surface vessels will be reinforced. Also, the land component is to be strengthened, as in February 2014 the strength of the Russian ground force in Crimea equaled 810 Marine Infantry Brigade (two battalions of marine infantry, an artillery battalion, an anti-aircraft battalion, a total of 2,000 soldiers). According to the existing plans, the brigade will be expanded by absorbing Ukrainian soldiers who have expressed a desire to serve in the Russian armed forces. Presumably, the coastal defense brigade will be restored. Additionally, in Crimea there will also

5 An agreement signed by the overthrown President Viktor Yanukovych with the then Russian President Dmitry Medvedev states that Russians will remain in Sevastopol for at least 25 years after the expiry in 2017 of an original term of leasing the base, with the possibility to extend this period until 2047.

6 This primarily concerns the North Crimean Canal, a pipeline which carries water from the Kakhovka Reservoir fed by the Dnieper river to supply the city of Kerch, $403 \mathrm{~km}$ away, and also for Simferopol, Sevastopol and other places. The energy balance is in much worse shape. Four-fifths of the electricity consumed in the region flows through high-voltage lines from Ukraine, via the Isthmus of Perekop. One third of the electricity generated in the area is solar energy, which cannot always be relied on. Also, the Kherson-Simferopol gas pipeline runs through the Isthmus of Perekop, transmitting gas for the whole peninsula.

${ }^{7}$ Earlier, it was planned that the six new Project 636.3 submarines will operate within the brigade from the port of Novorossiysk. In contrast to the Soviet times, the submarine tactical formation will not be stationed in Balaklava, but in the southern bay of Sevastopol. The first unit - Novorossiysk. 
be a land component of the Southern Military District in Crimea. No details have been developed so far, however, it may consist of one or two airborne brigades, twothree motorized infantry brigades and an armored brigade. The Russian Ministry of Defense will also develop the existing arms industry in Crimea, i.e., the optical plant (based in Feodosia), aviation facilities or shipyards.

By analyzing the development plans, it can be assumed that by the year 2020, Crimea may become a fortress in the Black Sea region, because practically every element of the military system - offensive and defensive, will be reinforced.

Also, the aviation potential in Crimea will be strengthened. After airfields upgrading, Su-27 fighters, maritime patrol and ASW aircraft Tu-142 and Il-38 will most likely operate from the airbase in Feodosia. There are also plans to expand a multi-layer air defense, despite the fact that currently there are S-300 and Pancyr$\mathrm{S} 1$ systems deployed in Crimea. A deployment of Tu-22M3 bombers is also considered, in response to the American anti-missile systems built in the Romanian base Deveselu (Aegis Ballistic Missile Defense - EPAA program with Aegis Ashore and SM-3 missiles) and any possible threats from the countries in the region or foreign fleets operating in the Black Sea.

\section{The Russian Air Force and Missile Forces as a Potential Threat to Ukraine's Air Defense System}

In the development and modernization plans of the Russian Armed Forces, a further increase (by 10-20\%) is planned with regard to its potential strike capability. This will be achieved by increasing the number of strategic, bomb and ground attack aircrafts, the modernization of fighter aircraft, as well as rearming the Air Force to a fifth generation multi-role aircraft.

It was also assumed that the acquisition of a strategic initiative and success in the war campaign can be achieved only as a result of active and definite operations, in the air and from the air. In accordance with these assumptions, the air force of the Russian Federation will be transformed into a versatile, powerful, highly maneuverable and effective combat system which will play a leading role in winning and maintaining air supremacy.

It was also assumed that in a global and regional conflict, the share of air force operations will constitute between 20-95\% compared to the overall effort of the armed forces (Kozłow, 1999, p. 58). The majority of these tasks are assigned to ground attack aircrafts. In the assessment of doctrinal assumptions concerning the use of the air force in the times of the USSR and those in the last decade, it may 
be concluded that in Russia's armed forces, there is a clear growth in the fight over gaining air supremacy in the theatre of operations ${ }^{8}$. What is more, the elimination of fighter-bomb aviation as a branch of aviation significantly extended the area of frontline combat operation by $70-450 \mathrm{~km}$, increasing the range of tasks up to $40 \%$ (Kozłow, 1999, p. 59). The above-mentioned quantitative and qualitative changes have led to the reclassification of tasks of the frontline combat aviation in air operations in the initial period of war. This particularly applies to launching the first massive air raid during an operation, in which frontline combat aviation, so far, focused its primary effort on the destruction of tactical aviation air bases. Currently, the frontline combat aircraft in the first massive air raids, during an operation, detaches up to $50 \%$ of its effort to suppress enemy ground air defense systems. The main ground attack force in an offensive air operation is intended for strategic aviation, including long-range bombers and strategic bombers which carry missiles. The changes made in the Russian air force should be considered highly unfavorable for the air defense of countries bordering Russia. This is due to the growth of potential capabilities in the massive use of aviation, and also of its other branches, already in an initial phase of an offensive air operation.

In accordance with the doctrinal assumptions, strategic aviation should be capable of carrying out tasks as part of operations of strategic nuclear forces and also of independent operations in cooperation with other air force assets. The evolution of views on the use of strategic aviation in Russia also applies to its use in local and regional warfare. In the future, it is to be included in the composition of formations operating on a predetermined strategic direction. It is designated for delivering conventional weapons, but in special cases, it can launch preventive nuclear strikes. Equipping strategic aviation in conventional and precise means of destruction gives it an opportunity to execute operational and tactical stand-off tasks from home bases, without entering the zone of active air defense means (Michalec, 2000, pp. 12-13). In the foreseeable future, the capabilities of strategic aviation are to be successively increased. After the expansion of a tanker fleet, their range of operation will rise. It will also allow the Air Force to quickly amass its effort on any strategic direction. At present, 37 Air Army is equipped with 32 turboprop bombers Tu-95MS6, $31 \mathrm{Tu}-95 \mathrm{MS16s}$ and $13 \mathrm{Tu}-160$ s, which can carry more than 850 cruise missiles. In accordance with these needs, it is possible to observe the devel-

8 In Soviet times, missile and artillery forces (MF and Ar. F.) were planned to engage 35-45\% of the tasks, army aviation (ArA) - 10-15\%, ground-attack aviation (GAA) - 5-6\%, fighter-bombers (FB) - up to $20 \%$, and frontline bombers (FIB) - up to $20 \%$. MF and Ar. F. affected at a depth of $350 \mathrm{~km}$, and FlB $-450 \mathrm{~km}$. ArA and FB operated at a depth of 50-200 km, whereas the effort of ArA focused at a depth of nearly $60 \mathrm{~km}$. 
opment of strategic airplanes. The Tu-60, Tu-95MS, and $\mathrm{Tu}-22 \mathrm{M} 3$ are equipped with new EW suites and new precision strike weapons.

According to Putin, another priority area is the development projects of unmanned aerial vehicles, including combat variations. In the coming years, Russia intends to allocate 13 billion US dollars for this purpose.

As a result of the implementation of development program, it was assumed that in 2020, the Russian Air Force will field 800 modern combat aircrafts. The suggested composition will comprise 50-75 strategic bombers. It should be noted, however, that their combat readiness (more recent design) and combat capabilities (e.g., comparing the Su-34 with the Su-24M) will rise.

When forecasting a possible start of Russia's air operations over Ukraine or over NATO's eastern flank, their scenario may resemble that of the war with Ossetia. In the course of these operations, only $40 \%$ of aircrafts operated from their home bases. The remaining ones were deployed to other locations, $15 \%$ of which were aerodromes of other military districts. One aerodrome was used, on average, by forty-two aircrafts, although none of the pre-war air bases was actively exploited by more than two thirds of the forces. One such aerodrome, which is not operated on a regular basis, was Mozdok. The ground-attack aircraft $\mathrm{Su}-25$ s engaged targets at a distance of $250 \mathrm{~km}$, the Su-24M launched attacks on distant targets, even up to $800 \mathrm{~km}$ from the base, and Tu-22M3 bombers up to more than $1,600 \mathrm{~km}$. The deployment distances did not exceed 1,100 km for the Su-24M, $750 \mathrm{~km}$ - for the $\mathrm{Su}-25$, and $550 \mathrm{~km}$ for the $\mathrm{Su}-27$. It should be noted, however, that during the exercises Zapad-2009, Su-25s were deployed at a distance slightly exceeding 1,100 km. The helicopters operated from frontline aerodromes, yet their home bases were distanced by no more than $500 \mathrm{~km}$ from the frontline of the operations.

In the event of a possible Russian attack on the eastern NATO flank, the Russian air force is likely to operate aerodromes in Belarus. When analyzing their location, it is obvious that within less than $50 \mathrm{~km}$ from the Polish border, there are four aerodromes. Another four aerodromes are located at a distance ranging from 50 to $250 \mathrm{~km}$ from the Polish border. At a distance ranging from 250 to $800 \mathrm{~km}$, there are thirteen aerodromes, and another one near the Lithuanian border. In addition, on the territory of Russia itself, there are ten aerodromes at a distance of $800 \mathrm{~km}$ from Poland, not counting another four aerodromes in the Kaliningrad Oblast at a distance of less than $60 \mathrm{~km}$ from the Polish border. The above analysis clearly shows that aerodromes should not limit the operations of Russian military aircrafts.

Maneuvering cruise missiles might pose a serious threat to targets and the very air-defense system of Ukraine, or possibly eastern part of NATO countries. These are unmanned, self-navigating destructive weapons, which can be launched from 
bombers (ALCM - Air Launched Cruise Missiles), ships (SLCM - Sea Launched Cruise Missiles) and submarines (GLCM - Ground Launched Cruise Missiles).

Cruise missiles usually bypass areas which are heavily defended by the air-defense system, performing flights at low or high altitudes'. The group of objects (targets) which are usually attacked by cruise missiles include the following:

- command posts and communications centers;

- railway junctions, roads and bridges and crossings on wide water obstacles;

- aerodromes, naval bases and air-defense missile launchers;

- assembly areas (formations) of land forces.

The strikes of cruise missiles can be performed without entering the zone of active air defense assets. When crossing the air-defense contact corridor (zone) and affecting the targets located deep, the main load of combating them should be taken by air-defense assets, deployed deep inside the defended area. In terms of the safety assessment of NATO eastern countries and the air-defense requirements, it is necessary to focus on a rather sizeable potential of this type of destruction assets, possessed by the armed forces of the neighboring countries.

Another dangerous threat to the air-defense system is ballistic missiles. A relatively large potential of ballistic missiles, which are currently in Russian, Ukrainian and Belarusian inventories, is worth paying attention to. Ballistic missiles belonging to the armed forces of these countries have a range of destruction of many crucial facilities located, for example, on the territory of Poland.

Quoting unofficial sources, at the end of 2011, within the land forces of the Russian Federation, there were approximately 40 Tochka complexes with defective onboard systems. Their number continues to grow. The missiles were used in the Georgian conflict in August 2008, presumably with very good results ${ }^{10}$.

The 9K79 Tochka is a tactical-level (army-corps-division) self-propelled missile launch system designed for transport, preparation and launching 9M79 missiles to combat small and large ground targets, deployed in the enemy combat formation (Miller \& Foss, 1994).

The 9K79 Tochka mobile missile launch system with 9M79F, 9M79K and 9M79B ballistic missiles mounted on a vehicle with a TEL-type launcher is de-

9 Usually cruise missiles use very low altitudes $(100-300 \mathrm{~m})$ and speed up to Mach 2. A major problem in their detection is a very small area of an effective radar cross-section equalling approximately $0.01 \mathrm{~m}^{2}$. Cruise missiles may manoeuvre with over $10 \mathrm{G}$ avoiding terrain obstacles.

10 In February 2012, a shooting exercise exploiting Tochkas was held in Belarus. They belonged to the 308 independent missile battalion, detached from the 465 missile brigade. The missile targets were within $60 \mathrm{~km}$. The fire was adjusted with UAVs from 927 Center for the Preparation and use of Unmanned Aerial Systems. 
signed for precision strikes. The primary targets are enemy fire and reconnaissance assets, command and control posts, maintenance units, ammunition and other material storage facilities. Tochka subunits can strike various targets, such as nuclear sites, strike and reconnaissance systems, air and missile defense assets, command posts, reserve assembly areas, rotary and fixed wing aircraft in airfields, weapons (of special use, i.e., nuclear) and ammunition stores, fuel depots and other material storage facilities as well as other equally critical objects, vulnerable to fragmentation attacks. The 9M79R version is used for the destruction of devices emitting electromagnetic radiation (radar stations, navigation and communications systems). The applied guidance system ensures minimum CEP (circular error probable). The accuracy is determined by a precise uploading of topographic data into the guidance system (in particular geographical coordinates of the launch and target coordinates) and by an initial orientation of missile gyros. According to studies, in favorable conditions it is possible to develop.

The air defense system of NATO's eastern flank is endangered by "Iskander" tactical ballistic rockets, deployed in Kaliningrad Oblast, as officially confirmed by Russia at the beginning of $2014^{11}$.

The "Iskander" system is designed to use conventional warheads to combat a variety of targets: missile and artillery systems; air defense systems; rotary and fixed wing aircraft at airfields (Dęga, 1995, p. 88); HQs and communications systems, critical economic and political infrastructure, and other objects. The subunits of tactical missiles could also engage the strike and reconnaissance systems, air and missile defense, HQs and operational reserve assembly areas. The high mobility of the system makes it difficult to be detected, mainly due to a very short launch missile phase. Every military district is to include one missile brigade, equipped with Iskanders with a range of up to $500 \mathrm{~km}$. The first of ten missile brigades (12 launchers) was assigned to the Leningrad Military District in July 2010. The complex is easy to airlift and its replacement was to be completed by 2016. Based on the analysis of its technical-combat capabilities, it can be concluded that within the

11 In mid-December 2013, the German newspaper "Bild”, allegedly after analyzing satellite images, reported the appearance of at least ten "Iskander" missile launchers in the Kaliningrad Oblast. When asked about the credibility of these reports, Sergei Lavrov flatly stated that the decision to deploy tactical missiles along NATO borders may be taken only on the basis of a current threat assessment. He also added that if military commanders regard such a move legitimate, they will have the final say about its implementation. "This is nothing personal. These are the rules of the game", he commented. The statement issued by the Ministry of Defense of the Russian Federation was even more vague to have claimed that the Operational and Tactical "Iskander" missile system entered missile and artillery arsenal in the Western Military District. 
range of "Iskander" missiles, which equals nearly $500 \mathrm{~km}$, virtually all important installations have been deployed on Polish territory (Kołata, 2015, pp. 96-124).

With regard to countering missile threats by the current air defense system on NATO's eastern flank, it is possible to observe its utter ineffectiveness, shown by its inability to intercept ballistic missiles of larger ranges, e.g., intermediate or intercontinental. Only Russia has such missiles in its inventory, with a range of $10,000 \mathrm{~km}$ to $16,000 \mathrm{~km}$. In consequence, in the event of an escalation of a conflict with Russia, eastern NATO's flank would be within the range of ballistic missiles, which, apart from carrying conventional warheads, are designed to carry nuclear loads.

In accordance with official sources, currently six Russian regiments are equipped with the S-400 systems. Three of them have been assigned to Moscow's defense system (Zwienigorod $50 \mathrm{~km}$ east of Moscow, Elektrostal $50 \mathrm{~km}$ east of Moscow, Dymitrov $65 \mathrm{~km}$ north of Moscow). The other three regiments (one for every military district) are assigned to the following military districts: Western, Southern, and Eastern. The Russian Federation also possesses a state-of-the-art anti-aircraft short range armament PANTSIR S-1 (NATO’s SA-22 Greyhound).

\section{Diagnosis of Ukraine's Air Defense System}

The Armed Forces of Ukraine consists of 139,000 soldiers and 45,000 civilians, however, the expenditure its $\mathrm{MoD}$ incurs of less than US $\$ 2$ billion, is very low. Currently, approximately $10 \%$ of the forces are in a state of operational readiness, another $10 \%$ is capable of achieving operational readiness within 30 days. For the remaining units, the required time, for this purpose, exceeds three months.

The Air Force of Ukraine has 40,000 soldiers and is equipped with 160 combat aircrafts, including up to 62 the MIG-29s (with 15-20 operational ones, including 4 modernized - including extending radar range by $20 \%$ - to MU version). The primary armament of combat aircraft is $\mathrm{CH}-25, \mathrm{CH}-29, \mathrm{CH}-59$ air-to-air and airto-ground guided missiles, $\mathrm{Kh}-25 \mathrm{MPa}$ and $\mathrm{Kh}-58$ anti-radiation missiles and airto-air R-27, R-60 and R-73 missiles.

The primary mission of the Air Force is protecting the airspace over Ukraine. In peacetime, this task is executed within air patrols aimed at air policing over the entire territory of Ukraine $\left(603,700 \mathrm{~km}^{2}\right)$. Combat air patrols also prevent possible incursions into the Ukrainian airspace along air borders (almost 7,000 km, including 5,600 km on land and 1,400 km sea borders).

A crucial element in the protection of air borders is air defense forces equipped with a variety of missile systems and radar stations. Along with the Air Force, they 
are responsible for the safety of the Ukrainian airspace. They are assigned to the Air Force Command. Every day, the tasks are performed by military personnel and over 2,200 civilian employees of the Air Force. On average, Ukrainian radars detect and track daily over 1,000 aerial targets. Due to a well-organized airspace control, the number of air incursions has dropped by $35 \%$ as compared to previous years, despite the fact that air traffic has increased by $30 \%$. The three commands play a crucial role in the structure of the Air Force and Air Defense Command. They are equipped with a definite air and missile potential.

Four hundred sets of air defense missile sets and radars are prepared to defend the country's airspace. The assets are assigned to Ukrainian air and missile defense.

Apart from the above-mentioned missile sets, we should also bear in mind a high potential of air defense assets available for the Land Forces. Organic air defense subunits, whose task is to ensure an efficient and direct protection from an aerial assault, are in their structure. TUNGUSKA, S-10, OSA, KUB mobile antiaircraft systems and IGLA and S-2M portable anti-aircraft man-portable, shortrange, air-defense systems are in the inventory of the anti-aircraft defense of the Land Forces. Overall, it is possible to identify over two hundred objects (areas) associated with air defense over the territory of Ukraine. It is assumed that the number includes about 135 active air defense missile sites operating in combat duties, while 133 locations field air defense systems, and 106 objects are so-called air defense service support units.

In Ukraine, early warning is executed by radars deployed around the entire country. In the sites (posts), on average, there are several types of radar stations. On the territory of Ukraine, there are forty-one active regions of electromagnetic radiation. The basis of airspace reconnaissance systems is a group of older radar stations from the former Soviet Union. They are often exploited in various configurations, which allows using the capabilities of individual radar systems. As a result, these systems are capable of practically monitoring the entire Ukrainian air space as well as a large part of the Black Sea and the Azov Sea.

In conclusion, it may be stated that the active air defense of Ukraine was organized to protect key industrial centers and the most important cities - in particular, geographical regions, mainly the capital city of Kiev and other important industrial centers such as Dnipropetrovsk, Kharkov, or Odessa. The majority of air defense posts have been scattered throughout the entire country along the western border. It is worth emphasizing that the whole territory of Ukraine is covered by a network of radar and electronic warfare stations, and the key regions and cities have a multilayer air defense, which ensures a strong cover against possible air strikes. The Integrated Air Defense System, which was created using all forces and assets from each 
branch of the armed forces, is efficient and economic, although it requires a strict and centralized control system. Ukrainian military commanders are aware that a modern air defense system must be multifunctional, able to fight not only with airplanes and helicopters, but also with missiles and other unmanned aerial vehicles (platforms). In this respect, it is assumed that the efficiency of air defense must be fulfilled by exploiting combat capabilities, taking into account cooperation, a centralized system of command, and control over the operations of aviation and missile air defense systems.

Thus, the achievement of high efficiency by Ukraine's air defense forces, within the existing political and military situation, is possible mainly in the conditions of forming a joint air defense system, following a coherent concept, properly divided tasks, taking into account the properties of its own reconnaissance, weapons and command assets.

\section{A Possible Threat to the Air Defense of Countries on the Eastern NATO's Flank}

In terms of the vast potential of aviation and the missile potential of Russia's armed forces, it is possible to make an overall assessment of the capability of the air defense system on NATO's eastern flank, which currently has limited possibilities of an efficient operation (Goniewicz, Goniewicz, \& Lasota, 2018, pp. 27-30). In this respect, it can be concluded that the present system of air defense can combat mainly traditional manned assets of an air strike. The possibilities of combating cruise missiles and state-of-the-art aircrafts by NATO's eastern flank countries' air defense systems seems limited. One should also be aware that effective air defense in the conditions of a high intensity conflict will be very difficult to achieve due to the limited ranges of anti-aircraft missile sets.

The inability to combat ballistic missiles by national air defense systems leads to a situation where in high intensity conflict conditions stationary installations in the area of NATO's eastern flank, which are critical for the capability of conducting a defense operation, may become exposed to the strikes of such assets. This is a highly unfavorable position that generates the hazard of the emergence of negative consequences in the operational and strategic dimension. The strikes of tactical ballistic missiles may interrupt the continuity of command at the strategic and operational levels or cause a delay in the deployment of allied forces in the country.

A diagnosis of the current state of the air defense system indicates a varied degree of satisfying global and European standards. The capabilities of detecting 
manned aircraft at distances and accuracy which is necessary for the use of active combat assets are on a relatively good level. The lack of a continuous use of aerial systems of airspace surveillance limits the ability to detect aircraft executing missions at low altitudes.

The ability to ensure the continuity of acquiring information by the national air defense systems on air threats in peacetime, crisis and war should be assessed as varied. While in times of peace and crisis, threats to the continuity of acquiring information about the aerial picture do not have to be anticipated, in high intensity conflict conditions, they may develop in a less favorable manner. The stationary nature of parts of the air defense system elements which are responsible for the collection and distribution of information about the air situation makes them a relatively vulnerable target to kinetic or electronic strikes of a potential adversary.

In the case of their impact, one should expect at least a temporary loss or a reduction in the air defense capability of ensuring a continuity of data acquisition and a distribution of information about air threats. However, it must be noted that due to the possession of organic airspace surveillance assets by air defense units, any distortions in the continuity of acquiring such information by other elements of the air defense would not adversely affect the use of anti-aircraft missile sets in a decentralized and autonomous manner. Such a situation, however, could have an adverse effect on the sustainability of the air defense system due to the disclosure of radar organic reconnaissance assets.

Given the stationary nature or a limited mobility of reconnaissance radar assets, the ability to concentrate the national effort of the air defense system with regard to data acquisition about air threats in a spatial and temporal dimensions and in relation to a particular category of air threats, should be evaluated negatively. The national air defense systems of NATO's eastern flank countries currently do not have the potential to safeguard full redundancy in the delivery of a role to inform about air threats.

In conditions of a high intensity conflict in the Euro-Atlantic area, there will be an increase in attacks by means of tactical ballistic missiles with improved maneuverability characteristics and increased resistance to counter air defense systems.

The tactical ballistic missiles will pose a threat to the stationary elements of the country's command and control system, armed forces and key elements of the potential of the armed forces determining the ability of the state to conduct a strategic defense operation in a national and allied dimension.

Owing to the proliferation of cruise missiles in the Euro-Atlantic area, they should be included in the assessment of operational conditions of the development of the air defense system. The assessment should primarily take into account the 
ability to detect and combat aerial objects of low effective radar cross-section, performing flight at transonic speeds at extremely small altitudes.

\section{Conclusions}

An escalation of the conflict in Ukraine will change the present order of security. It will constitute an immediate direct threat to NATO's eastern flank countries, which currently do not have combat potentials to counter the new threat. In the opinion of military experts, the efficiency and success of the air defense is perceived as a key (fundamental) issue for success in war. According to military experts, it can be achieved by a well-organized air defense system, characterized by a full integration in countering air threats - in times of peace, crisis and war. From this point of view, air defense has become an integral part of the air defense dimension. Integration in the air defense system, both from a perspective of allies and a nation, is considered as an ideal condition (still not attained, but one which is sought). Its essence is to combine efforts of all the components involved in air defense as one coherent entity.

Therefore, paying attention to the disproportion of potentials of countries on NATO's eastern flank and of Russia, it is necessary to improve combat capabilities through the modernization of national air defense systems. However, it needs to be stressed that despite the implementation of the modernization programs, including air defense systems in Poland (Vistula and Narew programs), it is a long process and its complete implementation is planned for 2025.

In view of the above, currently it is necessary to support more developed NATO countries with regard to this threat. It is possible to achieve this through the constant presence of the allied forces in the area of NATO's eastern flank. It will serve as a part of potential enemy deterrence.

\section{References:}

Cichocki, B. (2010). Doktryna wojskowa Federacji Rosyjskiej. Warszawa: BBN.

Cielma, M. (2014, April 8). Rosjanie organizuja się na Krymie [Russian's Organizing on the Crimea]. Retrieved from: http://dziennikzbrojny.pl/aktualnosci/ news, 2,6788, aktualnosci-z-europy,rosjanie-organizuja-sie-na-krymie.

Dęga, Cz. (1995). Uzbrojenie i pole walki wojsk lądowych do 2020 roku. Warszawa: Bellona. 
Giles, K. (2015). Russia and Its Neighbours: Old Attitudes, New Capabilities. In: K. Geers (Ed.). Cyber War in Perspective: Russian Aggression against Ukraine (pp. 19-28). Tallinn: NATO CCD COE Publications.

Goniewicz, K., Goniewicz, M., \& Lasota, D. (2018). Armed Forces Operation in the Scope of the Civilian Health Protection during Peacekeeping and Stabilization Missions: A Short Review. Safety and Defense, 4(1), 27-30. DOI: 10.37105/sd.9.

Jankowski, D. (2009). Nowa strategia bezpieczeństwa narodowego Federacji Rosyjskiej. Policy Papers, 35. Warszawa: Fundacja Amicus Europae. Retrieved from: https://docplayer.pl/24183027-Nowa-strategia-bezpieczenstwa-narodowego-federacji-rosyjskiej. html.

Kołata, G. (2015). Wybrane rakietowe środki napadu powietrznego Federacji Rosyjskiej. Zeszyty Naukowe AON, 4, 96-124.

Kozłow, K. (1999). Wojenno-wozdusznyje siły w sowriemiennoj wojnie. Wojennaja Mysl, 6, 23-35.

Larrabee, F.S., Pezard, S., Radin, A., Chandler, N., Crane, K., \& Szayna, T.S. (2017). Russia and the West after the Ukrainian Crisis: European Vulnerabilities to Russian Pressures. Santa Monica: Rand. DOI: 10.7249/RR1305.

Michalec, M. (2000). Operacje powietrzne wedtug pogladów rosyjskich [course development], Warszawa: AON.

Miller, D., \& Foss, Ch.F. (1994). Wspótczesna wojna ladowa. Warszawa: Espadon.

Sinicyn, W. (1998). Wojenno-wozdusznyje siły: Probliemy stanowlienija i razwitija. Wojennaja Mysl, 4, 64-75.

The Strategy of National Security of the Russian Federation by the Year 2020 (2009). Approved by the Decree of the President of the Russian Federation, no 537, signed by Dmitry Medvedev on May 12, 2009. 